\title{
Absence of c-Ki-ras gene mutation in malignant and premalignant Barrett's oesophagus
}

\author{
C Lagorce, J-F Fléjou, F Muzeau, D Hénin, F Potet
}

\begin{abstract}
Aims-To establish the prevalence of c$\mathrm{Ki}-$ ras gene mutations in codons 12 and 13 in 28 surgically resected Barrett's adenocarcinomas and 18 associated preneoplastic lesions in Barrett's oesophagus. Methods-Mutations were detected using the polymerase chain reaction followed by restriction fragment length polymorphism analysis. Human colon carcinoma cell lines with well characterised mutations in codons 12 and 13 were used as positive controls and to test the sensitivity of the method.

Results-c-Ki-ras gene mutations were not detected in any of the 28 specimens of Barrett's adenocarcinoma or in the 18 specimens of Barrett's oesophagus (nine non-dysplastic cases, three cases with low and six with high grade dysplasia).

Conclusions-These results suggest that the c-Ki-ras gene is not involved in the development of cancer in Barrett's oesophagus.
\end{abstract}

( $($ Clin Pathol: Mol Pathol 1995;48:M198-M199)

Keywords: c-Ki-ras gene mutations, PCR, Barrett's oesophagus.

Barrett's oesophagus is a condition in which the normal squamous epithelium of the distal oesophagus is replaced by a metaplastic columnar epithelium. It predisposes to the development of oesophageal adenocarcinoma at estimated rates at least 30 to 40 times greater than those seen in the general population. Dysplasia has been recognised as the precursor lesion of Barrett's adenocarcinoma according to a multistep model of carcinogenesis. ${ }^{1}$ It is therefore important to elucidate molecular events that predispose to neoplastic progression in patients with Barrett's oesophagus, in order to detect patients at high risk of cancer. Point mutations in the TP53 tumour suppressor gene are probably early and frequent events in the molecular mechanism leading to malignant transformation of Barrett's mucosa. ${ }^{2}$ Little is known about the mutations of the c-Ki-ras gene in oesophageal adenocarcinoma. The c-Ki-ras gene encodes a 21 kilodalton protein (p21) which demonstrates GTPase activity and appears to be involved in a normal cell signal transduction pathway. ${ }^{3}$ In cancers of the digestive tract c-Ki-ras has been found to be activated in most cases, especially in colon and pancreatic cancers.

The aim of this study was to establish the prevalence of c-Ki-ras mutations in codons 12 and 13 in surgically resected Barrett's adenocarcinomas and associated preneoplastic lesions.

\section{Methods}

TUMOUR SAMPLES

Twenty eight surgically resected specimens were collected from patients with Barrett's adenocarcinoma who underwent surgery at Beaujon hospital between 1990 and 1994. Of these specimens, 25 were from men and three from women. None of the patients had undergone chemo- or radiotherapy before surgery. All of the surgical specimens were received fresh, and samples of adenocarcinoma (in all cases) and of Barrett's mucosa adjacent to the tumour (in 18 cases (nine non-dysplastic, three with low and six with high grade dysplasia)) were snap frozen and stored in liquid nitrogen until DNA extraction was performed. The resected Barrett's oesophagus was then fixed in $10 \%$ neutral formalin and analysed for tumour stage and the grade of dysplasia in the surrounding mucosa.

\section{C-KI-RAS MUTATION ANALYSIS}

Genomic DNA was extracted with sodium dodecyl sulfate/proteinase $K$ using the phenol chloroform method. Detection of mutations in codons 12 and 13 of the c-Ki-ras gene was carried out using polymerase chain reaction (PCR) amplification and restriction fragment length polymorphism (RFLP) analysis as described by Jiang et al. ${ }^{4}$ Briefly, the primer sequences contained an altered base pair that artificially created restriction sites adjacent to or within the wild-type region of codons 12 or 13. Mutations were then scored by loss of the restriction pattern after digestion with the appropriate restriction endonuclease (Bst NI at codon 12 and $\mathrm{HaeIII}$ at codon 13). All specimens were re-evaluated in a second, separate PCR amplification. Human colon carcinoma cell lines with well characterised mutations in codons 12 (SW480) and 13 (HCT116, LOVO) were used as positive controls.

\section{Results}

The specificities and sensitivities of both of these assays were first evaluated as described by Jiang et $a l .{ }^{4}$ For both exons, the mutated band was still detectable at a 1 in 100 dilution. Therefore, the threshold of detection was one cell with a homozygous mutation in $10^{2}$ cells

with a wild-type c-Ki-ras gene. \\ Faculté Xavier Bichat, \\ $C$ Lagorce \\ J-F Flejou \\ Service d'Anato \\ Pathologiques, \\ J-F Fléjou \\ 23 March 1995
}




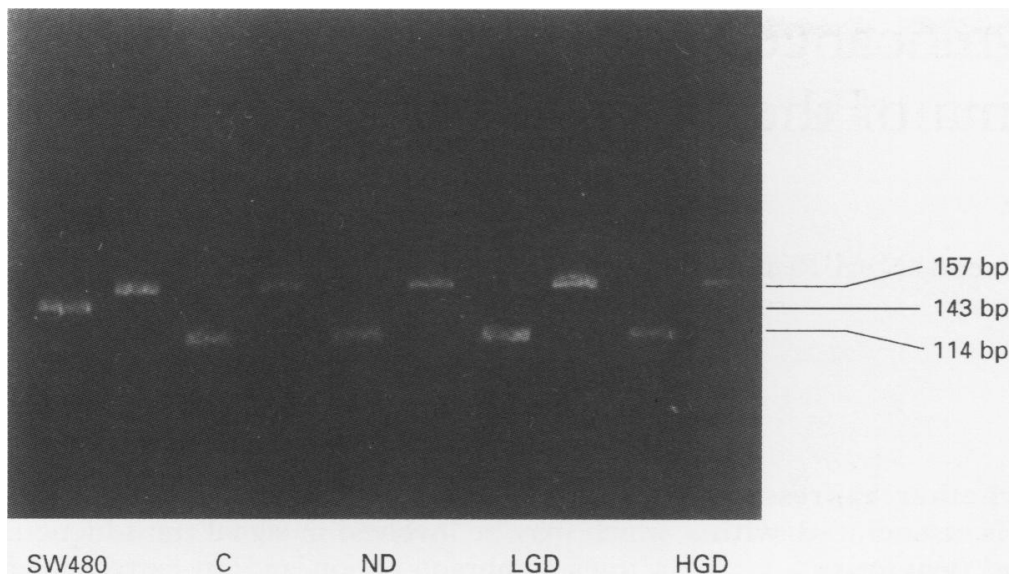

RFLP assay for c-Ki-ras mutations at codon 12 in malignant and premalignant Barrett's oesophagus. Samples are from different regions of the same specimen: $C$, carcinoma; $N D$, non-dysplastic Barrett's mucosa; LGD and HGD, Barrett's mucosa with low grade and high grade dysplasia. The samples are run in pairs of undigested and digested products. The PCR undigested product of the $c-K i$-ras gene shows a 157 base pair fragment (right lanes). BstNI digestion of the PCR product from wild-type c-Ki-ras gene codon 12 gives a 114 base pair fragment (left lanes). SW480 cell line: BstNI digestion of the PCR product from the homozygous mutated $c-K i$-ras gene codon 12 gives a 143 base pair fragment (left lane). ations in 12 cases of Barrett's oesophagus, five of whom also had adenocarcinoma.

Cancer developing in Barrett's oesophagus shares some similarities with that observed in ulcerative colitis. Both diseases are clinically characterised by a chronic inflammation of the mucosa, an increased incidence rate of adenocarcinoma, and a multistep carcinogenesis with dysplasia as the precursor lesion of adenocarcinoma. Our results suggest that the carcinogenic process arising in Barrett's oesophagus could be compared with that of colon cancer arising in ulcerative colitis. Specific genetic events underlying cancer arising in ulcerative colitis and sporadic colorectal cancer are different. In sporadic colorectal carcinoma $\mathrm{c}-\mathrm{Ki}$-ras gene mutation is a frequent event and appears to occur at an early stage in the adenoma-carcinoma sequence, while TP53 gene mutation is a frequent but late event. ${ }^{8}$ However, colon cancer complicating ulcerative colitis and Barrett's adenocarcinoma are genetically characterised by a lower prevalence rate of $\mathrm{c}-\mathrm{Ki}$-ras mutation, and early and frequent mutations in TP53 gene. ${ }^{27910}$

The results of this study suggest that the c-Ki-ras oncogene is not activated in adenocarcinoma arising in Barrett's oesophagus and underlines the need to identify other genetic events for screening those patients with Barrett's oesophagus at high risk of developing cancer.

\section{Discussion}

In this study, we did not detect any mutations in $\mathrm{c}-\mathrm{Ki}$-ras gene at codons 12 and 13 either in Barrett's adenocarcinoma (28 cases) or in samples of Barrett's mucosa taken close to the tumour (18 cases). The method we used to detect these putative mutations, PCR-RFLP, is sensitive, as shown by our àssay with mutated cell lines, specific and applicable to routine diagnostic practice. Moreover, PCR-RFLP analysis does not require the use of radioactivity.

Barrett's adenocarcinoma arises through a multistep carcinogenic process in which specialised metaplastic epithelium progresses to dysplasia and finally to cancer. This multistep process probably involves the mutational activation of one or several oncogene(s) coupled with the loss of several tumour suppressor genes. ${ }^{256}$ Recently, we have shown that mutations in the TP53 gene are present in a large majority $(88 \%)$ of cases of Barrett's adenocarcinoma, and occur at an early stage. ${ }^{2}$ The data presented here are in agreement with the only other report we found in the literature by Meltzer et al who did not detect any mut-
1 Dent J, Bremner G, Collen MJ, Haggitt RC, Spechler SJ Barrett's esophagus. $\mathcal{F}$ Gastrenterol Hepatol 1991;6:1-22.

2 Hamelin R, Fléjou J-F, Muzeau F, Potet F, Laurent-Puig $\mathrm{P}$, Fékété $\mathrm{F}$, et al. TP53 gene mutations and $\mathrm{p} 53$ protein immunoreactivity in malignant and premalignant Barrett's esophagus. Gastroenterology 1994;107:1012-18.

3 Douglas RL. Function and regulation of ras. Annu Rev Biochem 1993;62:851-91.

4 Jiang W, Kahn SM, Guillem JG, Lu SH, Weinstein IB Rapid detection of ras oncogenes in human tumors: applications to colon, esophageal, and gastric cancer. Oncoplications to colon,
gene $1989 ; 4: 923-8$. Pantazis CG, Barrett JM. Differential expression of c-myc and H-ras oncogenes in Barrett's epithelium. A study and H-ras oncogenes in Barrett's epithelium. A study Med 1991;115:880-5.

6 Sorsdahl K, Casson AG, Troster M, Van Meyel D, Inculet $R$, Chambers AF. p53 and ras gene expression in human study. Cancer Detect Prev 1994;18:179-85.

7 Meltzer SJ, Mane SM, Wood PK, Resau JH, Newkirk $\mathrm{C}$, Terzakis JA, et al. Activation of c-Ki-ras in human gastrointestinal dysplasias determined by direct sequencing of polymerase chain reaction products. Cancer Res 1990;50:3627-30.

8 Vogelstein B, Fearon ER, Hamilton SR, Kern S, Preisinger A, Leppert $\mathrm{M}$, et al. Genetic alterations during colorectal tumor development. $N$ Engl f Med 1988;319:525-32.

9 Burmer GC, Levine DS, Kulander BG, Haggitt RC, Rubin CE, Rabinovitch PS. C-Ki-ras mutations in chronic ulcerative colitis and sporadic colon carcinoma. Gastrocerative colitis and sporad
enterology 1990;99:416-20.

10 Yin J, Harpaz N, Tong Y, Huang Y, Laurin J, Greenwald $\mathrm{BD}$, et al. $\mathrm{p} 53$ point mutations in dysplastic and cancerous ulcerative colitis lesions. Gastroenterology 1993;104:1633
5 Abdelatif OMA, Chandler FW, Mills LR, McGuire BS esophageal cancer and Barrett's epithelium: a prospective 